\title{
REVIEW
}

\section{Composition and function of mucilage macroaggregates in the northern Adriatic}

\author{
Valentina Turk ${ }^{1, *}$, Åke Hagström ${ }^{2}$, Nives Kovač ${ }^{1}$, Jadran Faganeli $^{1}$ \\ ${ }^{1}$ Marine Biological Station, National Institute of Biology, 6330 Piran, Slovenia \\ ${ }^{2}$ School of Natural Science, Linnaeus University, 39182 Kalmar, Sweden
}

\begin{abstract}
The episodic hyperproduction of mucilage macroaggregates in the northern Adriatic Sea creates an important site for the accumulation, transformation, and degradation of organic matter. In this review, the structure and function of macroaggregate components in relation to their macrogel and colloidal fractions are discussed. High resolution electron microscopy showed a very complex structure, a honeycomb-like structure of the mucus macroagregates that might grow to macroscopic sizes. The process of the formation and microbial interaction with the physicochemical diversity of the organic matter pool is poorly understood. Whether the in situ bacteria react to the carbohydrate-rich mucus as an imbalance in its $\mathrm{C}: \mathrm{N}$ :P ratio or whether the mucus is in fact largely a bacterial construct in relation to high dissolved organic carbon levels is unknown. The majority of carbohydrate and protein macroaggregate pools are potentially degradable, while the great majority of lipids can be preserved in the water column and exported away or finally deposited on the seabed. Our present knowledge indicates that different macroaggregate fractions and components are subjected to compositional selective reactivity, with important implications for macroaggregate persistence. Future work should reconcile the discrepancies between bacterial ectoenzyme potential activities and biogeochemical degradation sequences based on actual measurements. The determination of biofilm architecture, particularly the spatial arrangement of microcolonies, has profound implications for the function of these complex communities. We need to improve our understanding of the dynamic relationship among bacteria, other microorganisms, and a variety of organic matter forms.
\end{abstract}

KEY WORDS: Macroaggregates · Microorganisms $\cdot$ Composition $\cdot$ Degradation $\cdot$ Northern Adriatic

\section{OCCURRENCE AND ORIGIN OF MACROAGGREGATES}

Macroaggregates of various sizes, colors, and shapes - classified as small flocs, macroflocs, stringers ( 1 to $25 \mathrm{~cm})$, clouds $(5-10 \mathrm{~cm}$ to $3 \mathrm{~m})$, creamy, and gelatinous surface layers (Stachowitsch et al. 1990) occur periodically in the northern Adriatic. Different ideas have been presented to explain the development of the mucilage aggregates in the northern Adriatic, and a recent overview of these can be found in Giani et al. (2005a). In most studies, the importance of phytoplankton for the formation of mucilage has been tested in combination with specific environmental factors, changes in community structure, nutrient limitation, cell lyses or viral attack, and reduced grazing pressure
(Kaltenböck \& Herndl 1992, Malej \& Harris 1993, Peduzzi \& Weinbauer 1993, Baldi et al. 1997, Azam et al. 1999, Granéli et al. 1999, Herndl et al. 1999, Myklestad 1999, Najdek et al. 2002, Manganelli \& Funari 2003, Degobbis et al. 2005, Kovač et al. 2005). In particular, diatoms are thought to play a key role in macroaggregate formation through the release, i.e. exudation, of polymeric substances mostly composed of heteropolysaccharides and to a lesser extent of lipids and proteins (Pajdak-Stós et al. 2001, Kovač et al. 2002, 2004, 2008).

The first report of mucilage appearance in the Adriatic dates back to 1729 (Fonda-Umani et al. 1989). In recent decades, the extent and frequency of occurrence of nuisance mucilage has increased, as has public discontent (Giani et al. 2005a). The formation of 
macroaggregates usually starts in late spring and is thought to be linked to previous changes in the seawater inorganic $\mathrm{N}: \mathrm{P}$ ratio rather than to the concentration of individual nutrients (Cozzi et al. 2004, Penna et al. 2009). The marked retention of fresh water and water column stratification in the northern Adriatic during this period also seems to contribute to the development (Degobbis et al. 2005). In addition, accumulation of mucilage organic matter (OM) is enhanced by the peculiar hydrological conditions of the northern Adriatic during summer when this sea region becomes isolated from the rest of the Adriatic with the formation of a gyre. This change is connected to an increased residence time of the water, development of a pycnocline, and low turbulent shear (Supić \& Orlić 1999). Estimates of the volume-specific carbon mass of mucilage-associated suspended matter that accumulated in the water column during mucilage events in 1997 and 2000 yielded values of about $50 \mathrm{mg} \mathrm{C}^{-1}$ for dense water column mucilage clouds (Malej et al. 2001). According to high microbial activity in the seawater, the process of mucus formation is a result of the combination of microbial activity and environmental conditions. Here, we intend to present and discuss the role of microorganisms in the formation of mucus aggregates. In order to further this understanding, mucilage samples were analyzed using different microscopic techniques. In addition, the chemical composition of young and ageing aggregates is presented in an attempt to describe the function (activity, role) of microorganisms in mucus aggregates.

\section{STRUCTURE AND CHEMICAL COMPOSITION OF MACROAGGREGATES}

The mucilage appears to be a highly structured matrix containing diverse microbial flora, colloidal organic debris, and inorganic particles. Light and epifluorescent microscopy showed a diverse microbial
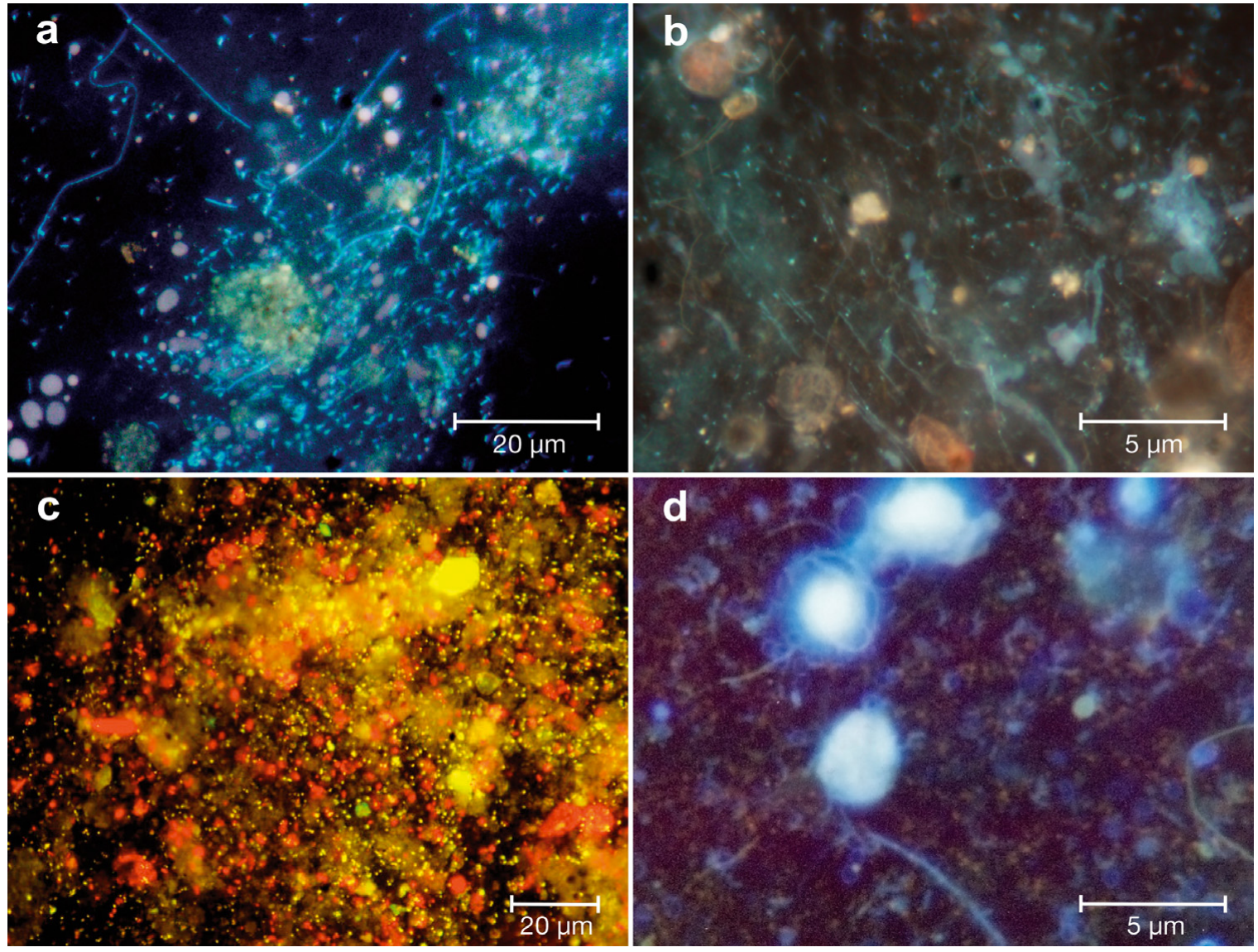

Fig. 1. Epifluorescent images of mucus samples in the Gulf of Trieste (northern Adriatic) (30 June 2004). Mucus samples were collected by divers, fixed with formaldehyde, and photographed by Olympus BH2 (DP70 soft). (a,b) DAPI (4', 6-diamino-2phenylindole $1 \mu \mathrm{g} \mathrm{ml}^{-1}$, final Sigma)-stained samples where heterotrophic bacteria of different size and forms are presented (UV filter set). (c) Autofluorescence of numerous cyanobacteria and unicellular Chlorococcus cells within a micro-millimeter mucus aggregate (magnification 200×). (d) Typical nanoflagellate cells with body scales visible after sample staining with DAPI (UV filter set) 
community attached to/in the mucus (Fig. 1). The most abundant organisms within the macroaggregates were bacteria, cyanobacteria, flagellates, and different diatoms. Different studies have demonstrated a highly variable composition of bacteria and phytoplankton in the mucilage during periods of macroaggregate formation in the northern Adriatic (Rath et al. 1998, Najdek et al. 2002, Kovač et al. 2005, Flander-Putrle \& Malej 2008).

A large number of samples were examined using transmission electron microscopy (TEM) or scanning electron microscopy (SEM) and showed the complex ultrastructure of the mucus macroaggregates. SEM analysis, using the high-pressure freezing method (Studer et al. 2008), showed a very complex network at low magnification (Fig. 2a). The inner core of the mucus consisted of fibers forming net-like structures. At higher magnification, it was possible to see fibers of different shapes and thickness, organized into complex networks (Fig. 2b,c). In the TEM images of thin mucus layers, the honeycomb-like structure is clearly visible (Fig. 3). A fibrilar, honeycomb structure can grow to macroscopic size in cultures and biofilms, but, as seen in Fig. 3, it also occurs in the free water mass ecosystem in the northern Adriatic. However, the process of macroaggregate formation and how heterotrophic bacteria interact in the seawater with the great physicochemical diversity of the OM pool is poorly understood.

Physicochemically, macroaggregates represent the transition between colloidal OM (macromolecules), into macrogels (matrix) and particulate OM (POM; Chin et al. 1998, Verdugo et al. 2004, Svetličić et al. 2005). The mechanism of gel formation can include crosslinking with covalent bonds, chain associations, and particle aggregation (Clark \& Farrer 1995). Polysaccharide gels can be built up through various physical interactions, including electrostatic, dipole, van der Waals, charge transfer, hydrophobic, and hydrogen bonding as well as double helix formation (Guenet 1992). The gelation process in mucilage formation probably encompasses first the assembling of gelator molecules (polysaccharides) into small clusters (fibrils, strands, ropes) and successively into a 3D volume-filling network (Raghavan \& Cipriano 2005). The agglomeration and stabilization of the macrogel could be enhanced by the association of colloids with cations and organic and inorganic particles (Kovač et al. 2004, Verdugo et al. 2004).

The total carbohydrate and protein contents of the macroaggregate matrix average about 14 and 5\%, respectively (Posedel \& Faganeli 1991, Faganeli et al. 1995, Penna et al. 2009). The carbohydrate and protein contents are matched by higher organic carbon, total nitrogen, and total phosphorus $\left(\mathrm{C}_{\text {org }}, \mathrm{N}_{\text {tot }}\right.$, and $\left.\mathrm{P}_{\text {tot }}\right)$ contents, averaging $16.4,0.7$, and $0.03 \%$, respectively.
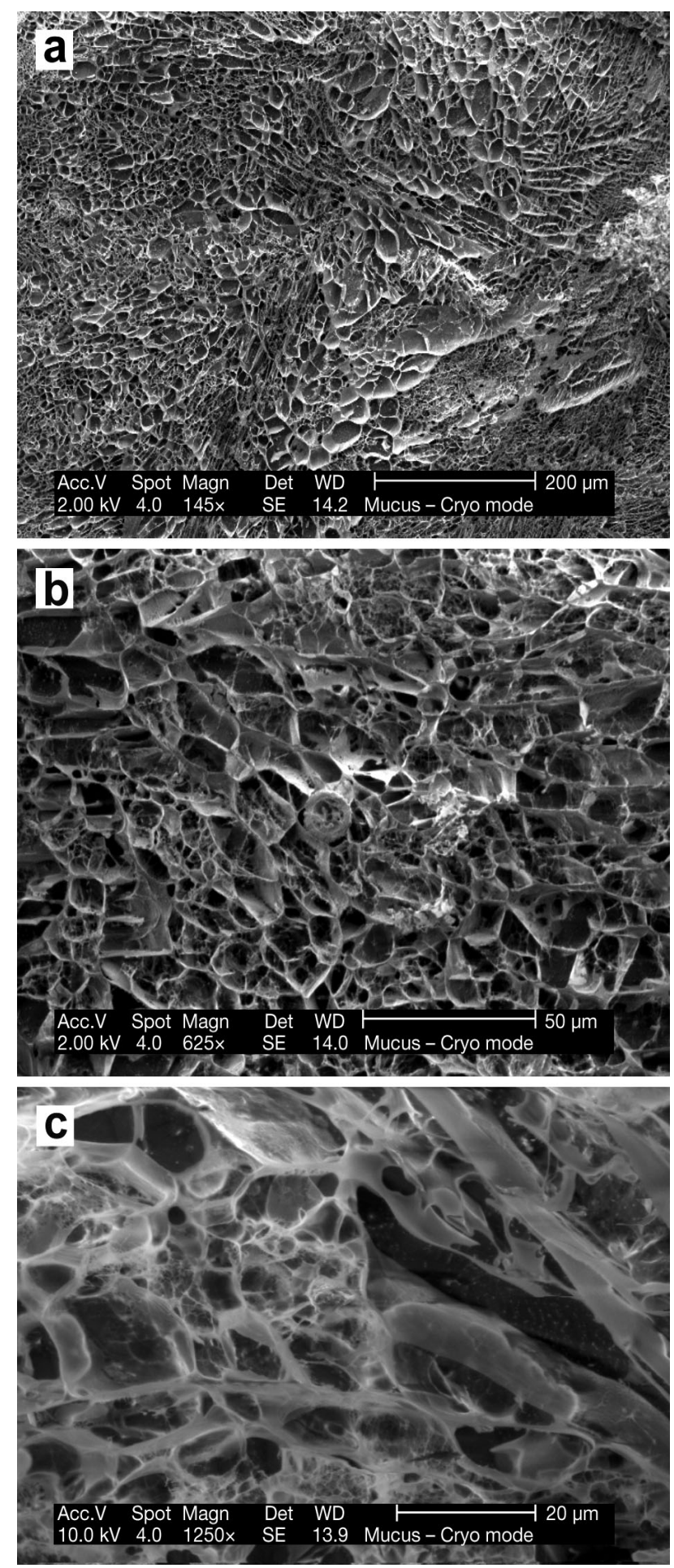

Fig. 2. Scanning electron micrographs of the mucus collected at $14 \mathrm{~m}$ depth in the Gulf of Trieste on 30 June 2004. Specimens were prepared using the high pressure freezing method and no other sample preparation (Cryo SEM, Philips XL20). (a) Sheets of material at lower magnification. (b) The inner core of the mucus consisted of fibers forming irregular network-like structures. (c) Network structures appeared to be made up of fibers of different thickness 

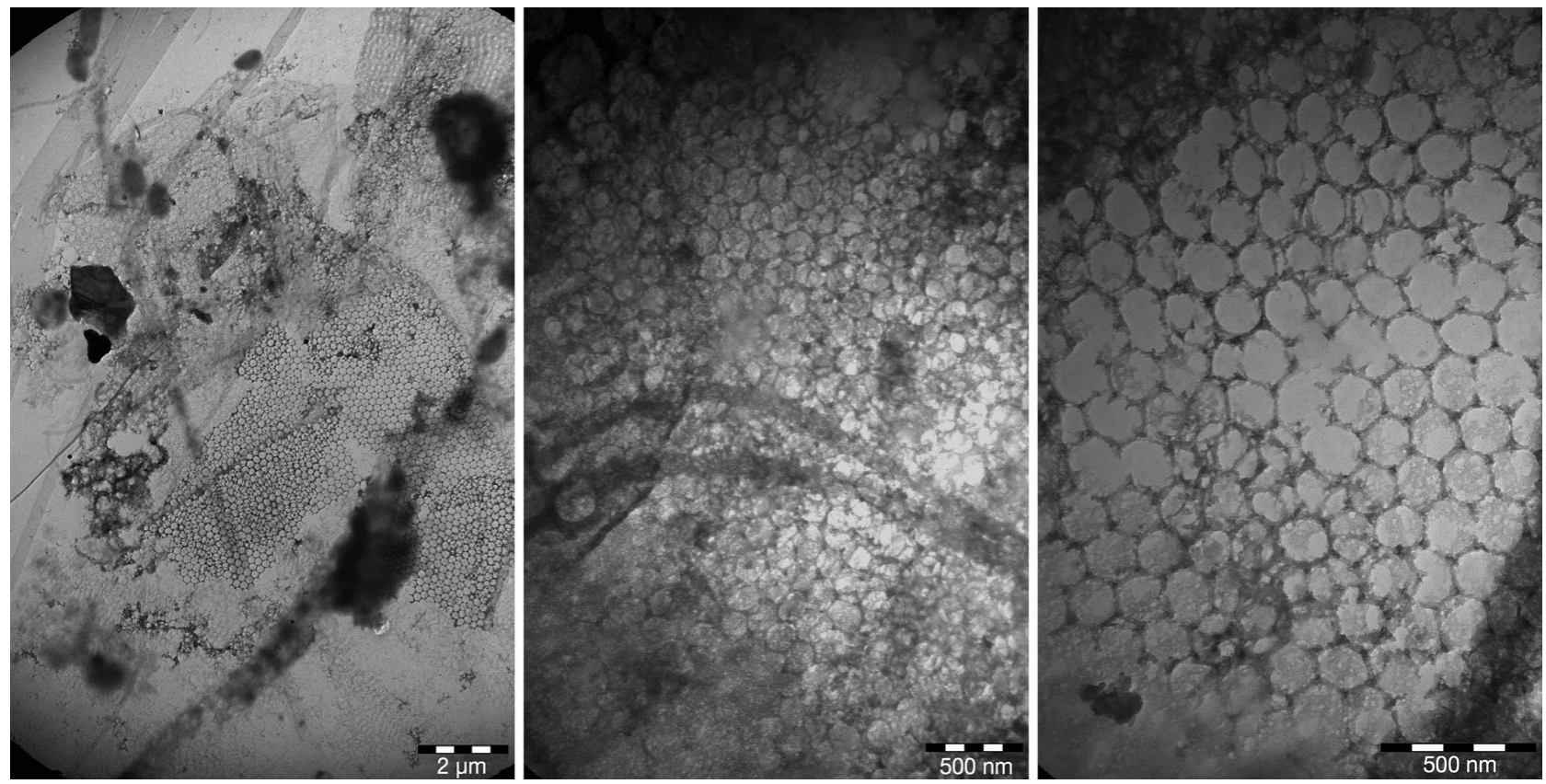

Fig. 3. Transmission electron microscopy images of the mucus aggregates from the northern Adriatic (30 June 2004). The images of ultra thin layers of mucus show a regular honeycomb structure (Jeol 100 CX electron microscope)

The percentages are normally lower in deeper, partially degraded mucus aggregates (average of total carbohydrate, $7.6 \%$; and total protein, $0.3 \%$ ).

The macroaggregate interstitial water colloids also show the presence of both basic constituents, i.e. carbohydrates and proteins (Fig. 4), while the bands assigned to lipids, i.e. aliphatic components, are less evident. In all sample analyses, cyanogenic glycosides were detected, which might represent the important part of organic nitrilated compounds, whose origin can be related to amino acids (Legras et al. 1990). The presence of carbohydrates in all colloid fractions was also confirmed by higher UV absorption spectral

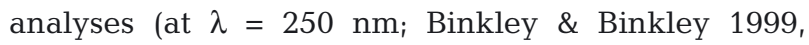
Giani et al. 2005b). The results of the carbohydrate content and the $\mathrm{C}: \mathrm{N}$ ratio within the higher molecular weight (MW) colloidal fraction (Fig. 5) suggest that Ncontaining carbohydrates can be important constituents of this fraction. The presence of the non-protein $\mathrm{N}$ compounds was also supported by $\delta^{15} \mathrm{~N}$ data exhibiting low values, especially in the $>30 \mathrm{kDa}$ fraction (Faganeli et al. 2009) in accordance with published isotopic data of non-protein nitrogen compounds, for example $\mathrm{N}$-acetylglucosamine (Smucker \& Dawson 1986), showing that a significant isotope depletion of these compounds, namely amino sugars as well as chlorophyll and nucleic acids, occurs due to enzymatic transamination (Macko et al. 1986, Sachs et al. 1999).

\section{ROLE OF MICROBES IN MACROAGGREGATES}

In the pelagic photic zone, nutrient limitation is believed to be a fundamental controlling factor for the community composition of microorganisms. Malfunc-

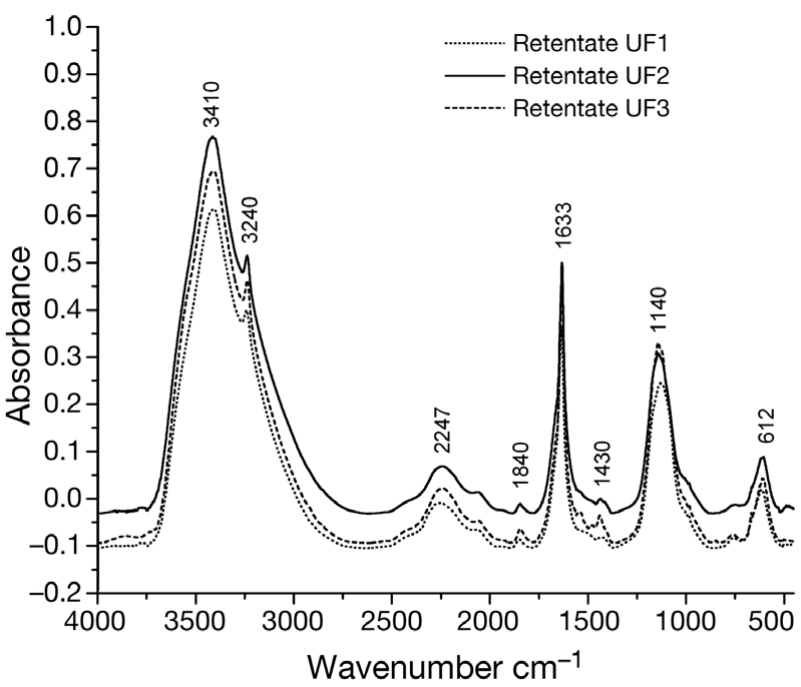

Fig. 4. Fourier transform infrared (FTIR) spectra of macroaggregate colloidal fractions (retentates) with nominal molecular weights of 30 to $10 \mathrm{kDa}$ (UF1), 10 to $5 \mathrm{kDa}$ (UF2), and $<5 \mathrm{kDa}$ (UF3); carbohydrate bands (region $\sim 1150$ to $900 \mathrm{~cm}^{-1}$ ), protein bands (region 1654 to $1635 \mathrm{~cm}^{-1}$ ), lipid bands (region 2950 to $2850 \mathrm{~cm}^{-1}$ ), and cyanogenic glycosides (nitrile) band (at $2240 \mathrm{~cm}^{-1}$, assignment after Nishikida \& Hannah 1996) 


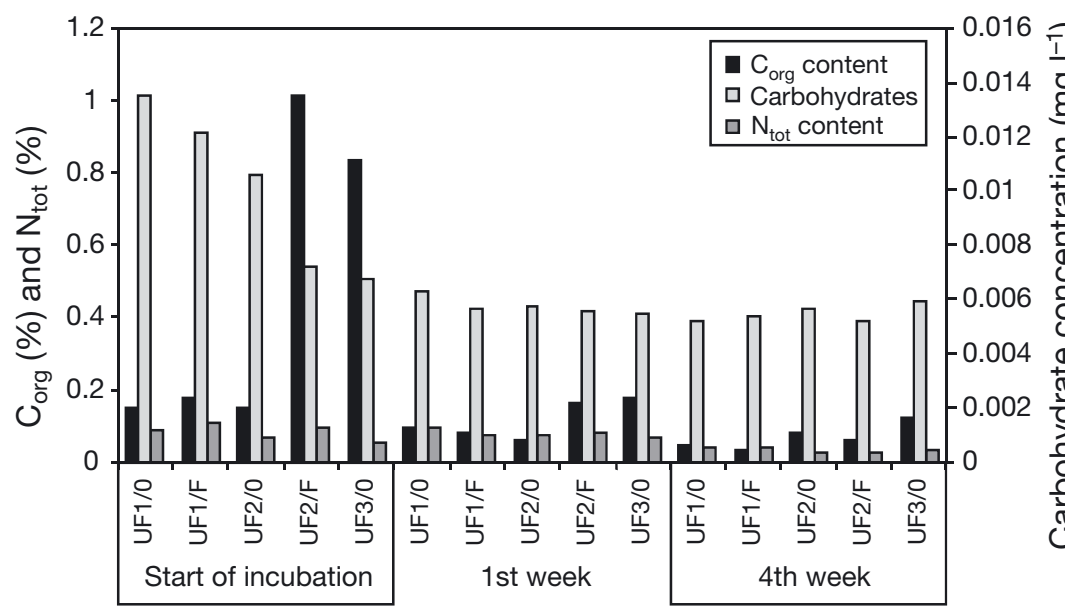

Fig. 5. Organic carbon $\left(\mathrm{C}_{\text {org }}\right)$, total nitrogen $\left(\mathrm{N}_{\text {tot }}\right)$ (Hedges \& Stern 1984), and total carbohydrate (Dubois et al. 1956) contents in macroaggregate colloidal fractions (ultrafiltration permeates UF/F and retentates UF/0) with nominal molecular weights of 30 to $10 \mathrm{kDa}$ (UF1), 10 to $5 \mathrm{kDa}$ (UF2) and $<5 \mathrm{kDa}$ (UF3) during $4 \mathrm{wk}$ of incubation at $26^{\circ} \mathrm{C}$ in the dark

tioning of the microbial loop has been proposed as a common feature for the accumulation of dissolved OM (DOM) in marine systems, wherein P-limited bacteria are unable to consume dissolved organic carbon (DOC) as fast as it is produced (Thingstad et al. 1997). Multi-year studies of microbial processes in the coastal northern Adriatic Sea showed elevated concentrations of DOC during high-primary-production seasons (Fonda Umani et al. 2007) and the accumulation of dissolved and colloidal polysaccharides resistant to degradation (Azam et al. 1999) as a source material for mucilage. The release and accumulation of polysaccharides were studied in different controlled enrichment experiments, but mainly to understand the relationship between nutrient limitation, DOM accumulation, and microbial response (Fajon et al. 1999, Malej et al. 2003). Bacterial abundance and production are considerably higher in the aggregates (MüllerNiklas et al. 1994) compared to concentrations in surrounding water. During summer, the Adriatic Sea is P-limited, and the dominance of large rod- and vibrioshaped bacteria has been recorded in some other parts of the Mediterranean Sea (La Ferla \& Leonardi 2005). Recently it was proposed that the growth of bacteria under nutrient limitation conditions depends on the 'surface:cell requirement of limiting element' ratio (Thingstad et al. 2005). This observation fits very well with the response observed for the single organism Vibrio splendidus, which increases in size during nutrient starvation as a means of gaining better uptake properties (Løvdal et al. 2008). Whether the in situ bacteria react to the carbohydrate-rich mucus as an imbalance in the C:N:P ratio like $V$. splendidus does, or whether the mucus is in fact largely a bacterial construct in relation to high DOC levels, is unknown. On the other hand, mucus formation in relation to bacterial growth is well known as, for example, in the case of plaque formation on teeth, biofilm formation on marine surfaces, and extensively in the carbon-rich environment of the pulp and paper production process. In all cases, mucus formation is governed by an adaptive benefit for the bacteria, which suggests that the formation of mucilage macroaggregates in the Adriatic should provide a benefit for the microorganism that produces the mucus.

Bacterial cells comprise the largest living surface in marine environments, and bacterioplankton release DOM to form gel (Heissenberger et al. 1996, Stoderegger \& Herndl 1999). The importance of microalgal-bacterial interactions within marine snow and the release of extracellular material have been emphasized previously (Heissenberger et al. 1996, Leppard et al. 1996). Heissenberger et al. (1996) observed that particle- associated bacteria exhibit larger envelopes than free-living bacteria, but the fate of these structures was not studied further. The microbial species that may form regular structures, including 'honeycombs' or 'veils,' have been studied mainly in biofilms from cultures or aquatic environments (Dalton et al. 1996, Trichet et al. 2001, Schaudinn et al. 2007 and references therein). Mucus aggregates, comparable to biofilms, could be defined as assemblages of microorganisms and their associated extracellular products attached to an abiotic or biotic surface (Davey \& O'Toole 2000). Biofilm microorganisms demonstrate physiological and morphological changes during their transition from planktonic growth to surface-attached community formation (O'Toole et al. 2000, Whiteley et al. 2001, Sauer et al. 2002). A range of behavior patterns in different surface-colonizing bacteria has been studied, and it is evident that the processes are highly regulated. Bacterial cells surround themselves to form microcolonies whose shape and structure are determined by cell-to-cell signals and are influenced by environmental conditions. Some Gram-negative marine bacteria associated within marine snow produce communication signals involved in quorum sensing, such as acylated homoserine lactones that are responsible for phenotypic behavior (for biofilm formation and exoenzyme production) when the population reaches high densities (Gram et al. 2002). There is also recent literature based on genomic interferences that pelagic bacteria produce surface 
polysaccharides and proteins for interaction with particles and organisms (Moran et al. 2007). Recently, Malfatti \& Azam (2009) showed that bacteria themselves produced cell-surface architectures that served as the structural basis for the networks at nanometer to micrometer scales. High-resolution atomic force microscopy analyses showed the interconnection of cell-surface gel matrices between microbial cells. The phylogenic specificities of microbes, their high abundance, and potential for aggregation to form complex networks are confirmed as quantitatively significant processes and may influence the biochemistry of the mucus macroaggregates.

\section{MACROAGGREGATE DEGRADATION}

In this review, we assume that the mucilage forms as the result of an unbalanced C:N:P ratio in the water column, which can favor extensive mucus structures that would benefit the organism in some specific way. This also means that the mucus must have a lifecycle initiated and growing as long as the microbes can take advantage of the mucus environment. With changing environmental conditions, the mucus environment can no longer offer a selective advantage, and thus the mucus starts to become old and a degradation process is initiated.

Bacteria are the principal decomposers of biopolymers in macroaggregates (Müller-Niklas et al. 1994, Mingazzini \& Take 1995). Macroaggregate degradation is supported by high bacterial abundance and activity, and by an efficient recycling of nutrients, which seem dependent on aggregate type and age (Del Negro et al. 2005). Bacterial extracellular enzymes are important catalysts in the degradation of macroaggregate OM to DOM, significantly influencing the marine biogeochemical cycling of organic carbon and other elements that limit microorganism growth. The formed low MW products (<600 Da) can be taken up by heterotrophic prokaryotes (Nagata 2000, Conan et al. 2007) and are substrates for subsequent transformations including microbial and photochemical degradation, and polymerization (Kovač et al. 1998). The quality of OM, including its C, N, P stoichiometric balance, determines the proportion between biomass production and remineralization (Obernosterer \& Herndl 1995, del Giorgio \& Cole 2000). Moreover, the transformation and degradation of macroaggregate OM encompass size- and compositional-dependent reactivity changes (Benner 2002). The degradation of sinking macroaggregates, enriched in the interstitial water oxygen concentration, is dependent on their residence time (Ploug et al. 1999), which is connected to the stratification of the northern Adriatic seawater column and the formation of the summer gyre (Supić \& Orlić 1999).
However, we found only a slight increase of C:N ratios (from 23 to 25, molar) in the water column macroaggregate matrices, suggesting a parallel degradation (similar degradation kinetics) of macroaggregate carbohydrates and proteins in the summer stratified seawater column (Posedel \& Faganeli 1991). This finding differs from those reported by others in the northern Adriatic, i.e. significant increasing C:N ratios in older macroaggregates (Del Negro et al. 2005). Our observation was further supported by Fourier transform infrared (FTIR) spectroscopy analyses showing the presence of carbohydrates and proteins in surface and water column samples while lipid contents were lower (Fig. 6). The selective degradation of bulk macroaggregate carbohydrates is reflected in the neutral monosaccharide composition showing decreasing glucose content with macroaggregate age (Faganeli et al. 1995, Giani et al. 2005b).

According to $\mathrm{C}_{\text {org }}, \mathrm{N}_{\text {tot }}$ (Fig. 5), and high performance size-exclusion chromatography (N. Koron et al. unpubl.) analyses, the degradation of macroaggregate colloidal fractions proceeds faster in the $>30 \mathrm{kDa}$ and 30 to $10 \mathrm{kDa}$ fractions compared to the 10 to $5 \mathrm{kDa}$ fraction. The differences in reactivity can again be explained by higher levels of N-containing polysaccharides in the higher MW fractions and rapid degradation of carbohydrates in all studied fractions leading to the preservation of organic nitrogen in aged degraded ('mature') macroaggregates. Recent reports underscore up to a 3-fold faster microbial degradation of the carbohydrate component of glycoproteins compared to the proteinaceous component (Ogawa et al. 2001, Nagata et al. 2003).

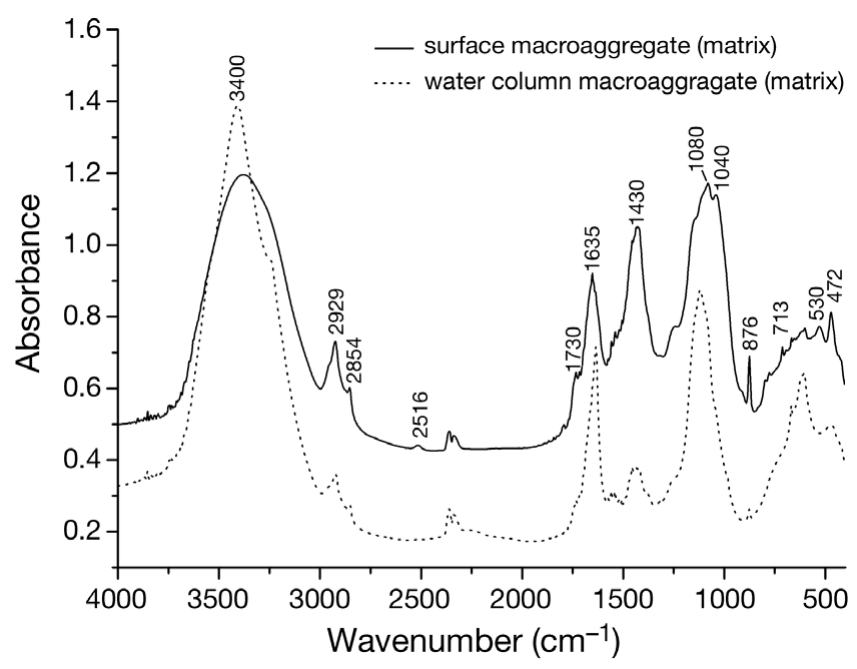

Fig. 6. Fourier transform infrared (FTIR) spectra of surface and water column macroaggregate matrix; carbohydrate bands (region $\sim 1150-900 \mathrm{~cm}^{-1}$ ), protein bands (region $1654-1635 \mathrm{~cm}^{-1}$ ), lipid bands (region $2950-2850 \mathrm{~cm}^{-1}$ ), and inorganic (mineral) components (region $<1000 \mathrm{~cm}^{-1}$ ) 


\section{ENZYMATIC HYDROLYSIS OF MACROAGGREGATES}

Bacteria associated with macroaggregates exhibit a very high potential enzymatic hydrolysis compared to free-living cells in the surrounding water (Del Negro et al. 2005, Zoppini et al. 2005), and high potential aminopeptidase activity suggests that proteins are degraded more rapidly than other constituents (Simon et al. 2002), which is in accordance with the reported preferential degradation of organic $\mathrm{N}$ compared to $\mathrm{C}$ in aggregates (Grossart \& Ploug 2001) and marine snow (Müller-Niklas et al. 1994). This can be reflected in a progressive increase of carbon content in the macroaggregates. The potential activity of lipase, one of the most active ectoenzymes of aquatic bacteria (Zoppini et al. 2005), was also found to be very effective in macroaggregates. Glucosidase activity was reported to be lower compared to aminopeptidase activity. It was also proposed that the rapid hydrolysis of proteinaceous material implies its large availability for bacteria (Zoppini et al. 2005). However, Danovaro et al. (2005) found high $\beta$-glucosidase activity in the northern Adriatic waters in summer during a mucilage event. The lower contribution of potential polysaccharide hydrolytic activity can lead to enrichment in polysaccharide content presumably rich in refractory compounds. The most detectable $\beta$-glucosidase activity can indicate the shift towards a more refractory $\beta$-glucosidic bond in aged macroaggregates (Müller-Niklas et al. 1994). The potential hydrolysis of organophosphorus compounds by alkaline phosphatase indicated slower $\mathrm{P}$ cycling compared to $\mathrm{N}$ (peptidase activity) and, thus, an increasing bacterial $\mathrm{P}$ limitation in aged macroaggregates (Zoppini et al. 2005)

This 'spectrum' of potential extracellular enzymatic activities was not directly reflected in the chemical composition of the progressive aged macroaggregates or in laboratory degradation experiments. During the incubation of macroaggregates, carbohydrates and proteins decreased rapidly, but a slower decrease of lipids, only at the end of the experiment, was presumably due to lower lipid degradability (Fig. 6). This observation was in agreement with previously reported studies using ${ }^{1} \mathrm{H}$-nuclear magnetic resonance (NMR) spectroscopy performed on bulk macroaggregates collected in situ, showing that carbohydrates degrade much faster than lipids (Kovač et al. 2002). The study of laboratory-based degradation of macroaggregate carbohydrates by the addition of cultured bacterial strains, isolated from the Gulf of Trieste, in parallel with bacterial cell counting and bacterial production revealed a rapid increase of dissolved carbohydrate concentrations followed by a slow decrease (Fig. 7). The latter was probably due to
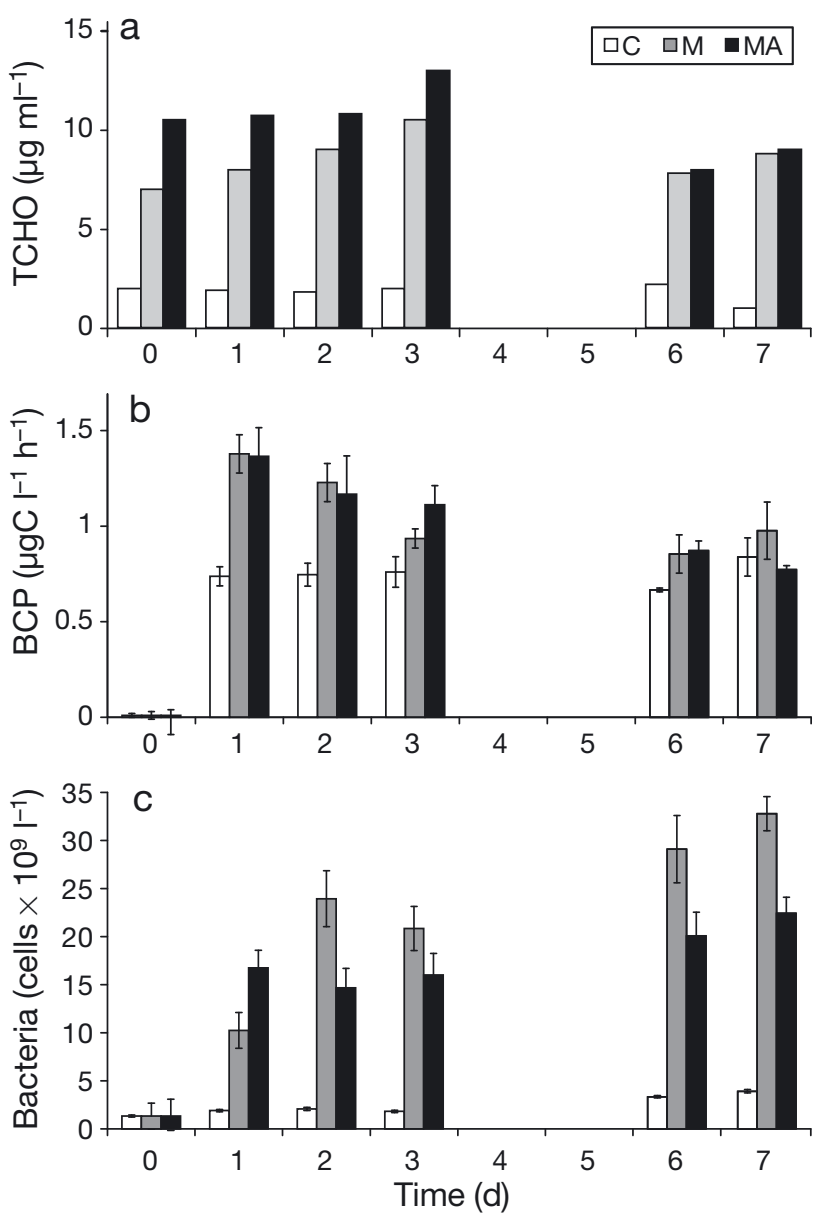

Fig. 7. (a) Concentrations of total dissolved carbohydrates (TCHO), (b) bacterial carbon production (BCP), and (c) bacterial abundance during the macroaggregate degradation experiment (C: control, $\mathrm{M}$ : addition of bacterial isolates, MA: addition of bacterial isolates and inorganic $\mathrm{N}, \mathrm{P}$ nutrients). TCHO were measured according to the protocol of Dubois et al. (1956), BCP by the ${ }^{3} \mathrm{H}$-leucine incorporation and centrifugation method (Smith \& Azam 1992), and bacterial abundance with DAPI staining (Porter \& Feig 1980). Error bars are $\pm \mathrm{SD}$

higher bacterial uptake evidenced by increasing bacterial biomass and bacterial carbon production. The simultaneous addition of inorganic $\mathrm{N}$ and $\mathrm{P}$ nutrients had a negligible effect on bacterial density and production, suggesting that bacterial C-uptake should not be severely limited by inorganic nutrients, and exhibited a rather limited effect on carbohydrate release.

\section{‘BIOAVAILABLE' MACROAGGREGATE POOL}

The bulk macroaggregates from the Gulf of Trieste (2004) contained about $14 \%$ carbohydrates and $5 \%$ proteins (Penna et al. 2009). The enzymatically hydrolyzed carbohydrates and proteins comprised about 70 and 
$>50 \%$, respectively, of carbohydrate and protein pools in surface and water column macroaggregates. Both constituents, probably bonded into glycoproteins, can be degraded in parallel. The percentages were similar to those estimated from chemical analyses of particulate and sedimenting OM containing macroaggregates in the summer stratified seawater column in the Gulf of Trieste (Posedel \& Faganeli 1991). The bacterial degradation of macroaggregate polysaccharides studied in vitro confirmed the rapid release of dissolved carbohydrates and later a slowed decrease, probably due to higher bacterial activity. The remaining less-degradable polysaccharides, containing more $\beta$-glycosidic linkages, and low-degradable proteinaceous matter significantly contribute to macroaggregate persistence. This indicates that the degradation, persistence, and accumulation of macroaggregates are biochemically fractionated and could not simply be the result of rather low bacterial glucosidase activity observed in the northern Adriatic (Zaccone et al. 2002). Considering the macroaggregate lipid content of about $2 \%$ (Penna et al. 2009), the hydrolyzed lipids should comprise only about $30 \%$ of the total lipid pool. Hence, most of the macroaggregate lipids including glycolipids, contrary to more degradable carbohydrates and proteins, would persist in the summer stratified water column (Kovač et al. 2002) and would finally be deposited on the seabed and transported southward into the deeper basin (Fonda Umani et al. 2007). The lability of the macroaggregate colloidal fraction is also dependent on its composition. Since the polysaccharide component in the lower MW colloidal fraction seems more degradable compared to N-containing polysaccharidic material, the higher MW fraction represents a possible path of organic nitrogen preservation in marine organic colloids. As a concurrent process, the photochemical degradation of macroaggregate colloids cleaves glycosidic bonds, producing oligomers and monomers (Kovač et al. 1998). All of these aspects can also have an important impact on metal, for example $\mathrm{Hg}$, and OM interactions leading to metal immobilization as well as its release into the seawater medium (Guo \& Santschi 2007). Future work should reconcile the discrepancies between observed macroaggregate ectoenzyme potential activities and biogeochemical degradation sequences and enzyme hydrolysis. This difference underlines the important relationship between substrate composition and its lability.

\section{CONCLUDING REMARKS}

Mucilage is a compact and dense material, with a huge heterogeneity in its network, chemical, and organism composition and structures. Conformation changes in macromolecules and their complexes after a phytoplankton bloom are of enormous interest to understand the role of dissolved and colloidal OM and its aggregation to form mucilage under relevant ecosystem conditions. The chemical composition of such aggregates is influenced by various factors, including nutrients, temperature, $\mathrm{pH}$, physiology, and age of the aggregate. The available information is inadequate to explain the origin/mechanisms of mucus aggregate formation in both laboratory and field studies. Microbial extracellular polymeric substances as such are widely distributed in marine environments and act as hotspots for the transformation of OM and modification of the micro-environment. Laboratory studies of these microenvironments are few, and lack of appropriate tools restricts in situ studies of various processes occurring in these micro-niches. According to the complexity of the mucus material, a combination of techniques is required to access the different parameters which contribute to mucilage formation: organic and inorganic compounds (molecules) and microorganisms.

Recent and continuous methodological advances in marine microbiology will allow better imaging and analytical techniques to determine structure on a (sub)micrometer scale, with non-destructive methods. The determination of biofilm architecture, particularly the spatial arrangement of microcolonies, might have important implications for the function of these complex biochemical structures.

Another area that has not been explored much is the change in bacterial diversity during aggregation and degradation of macroaggregates. Intensive studies using new molecular techniques need to be carried out to assess the microbial diversity and reveal the changes in microbial community during the production and degradation of mucus macroaggregates. Future work should also be focused on bacterial ectoenzyme activities and biogeochemical degradation processes within the water column as well as above the bottom, since the mucus macroaggregates represent a danger to seafloor communities (Schiaparelli et al. 2007).

Acknowledgements. This research was financed by the Slovene Research Agency (P1-0237, J1-2136). We are grateful to F. Tatti (FEI com Italy), L. Bonzi (University of Florence), and M. Heldal (Marine Microbiology, Institute for Biology, University of Bergen) for providing assistance with electron microscopy, and anonymous reviewers for their critical and valuable comments on the manuscript.

\section{LITERATURE CITED}

Azam F, Fonda Umani S, Funari E (1999) Significance of bacteria in the mucilage phenomenon in the northern Adriatic Sea. Ann Ist Super Sanit 35:411-419

Baldi F, Minacci A, Saliot A, Mejanelle L, Mozetic P, Turk V, Malej A (1997) Cell lysis and release of particulate polysaccharides in extensive marine mucilage assessed by 
lipid biomarkers and molecular probes. Mar Ecol Prog Ser 153:45-57

Benner R (2002) Chemical composition and reactivity. In: Hansell DA, Carlson CA (eds) Biogeochemistry of marine dissolved organic matter. Elsevier, Amsterdam, p 367-404

Binkley ER, Binkley RW (1999) Carbohydrate photochemistry. American Chemical Society, Washington, DC

Chin WC, Orellana MV, Verdugo P (1998) Spontaneous assembly of marine dissolved organic matter in polymer gels. Nature 391:568-572

Clark AH, Farrer DB (1995) Kinetics of biopolymer gelation implications of a cascade theory description for the concentration, molecular weight, and temperature dependences of the shear modulus and gel time. J Rheol 39: 1429-1444

> Conan P, Sondergaard M, Kragh T, Thingstad F and others (2007) Partitioning of organic production in marine plankton communities: the effects of inorganic nutrient ratios and community composition on new dissolved organic matter. Limnol Oceanogr 52:753-765

Cozzi S, Ivančić I, Catalano G, Djakovac T, Degobbis D (2004) Dynamics of the oceanographic properties during mucilage appearance in the Northern Adriatic Sea: analysis of the 1997 event in comparison to earlier events. J Mar Syst 50:223-241

Dalton HM, Goodman AE, Marchall KC (1996) Diversity in surface colonization behavior in marine bacteria. J Ind Microbiol Biotechnol 17:228-234

- Danovaro R, Armeni M, Luna GM, Corinaldesi C and others (2005) Exo-enzymatic activities and dissolved organic pools in relation with mucilage development in the Northern Adriatic Sea. Sci Total Environ 353:189-203

Davey ME, O'Toole GA (2000) Microbial biofilms: from ecology to molecular genetics. Microbiol Mol Biol Rev 64: 847-867

> Degobbis D, Precali R, Ferrari CR, Djakovac T and others (2005) Changes in nutrient concentrations and ratios during mucilage events in the period 1999-2002. Sci Total Environ 353:103-114

del Giorgio PA, Cole JJ (2000) Bacterial energetics and growth efficiency. In: Kirchman D (ed) Microbial ecology of the oceans. Wiley-Liss, New York, NY, p 289-325

Del Negro P, Crevatin E, Larato C, Ferrari C and others (2005) Mucilage microcosms. Sci Total Environ 353:258-269

> Dubois M, Gilles KA, Hamilton JK, Rebers PA, Smith F (1956) Colorimetric method for determination of sugars and related substances. Anal Chem 28:350-356

- Faganeli J, Kovač N, Leskovšek H, Pezdič J (1995) Sources and fluxes of particulate organic matter in shallow coastal waters characterized by summer macroaggregate formation. Biogeochemistry 29:71-88

Faganeli J, Ogrinc N, Kovač N, Kukovec K, Falnoga I, Mozetič P, Bajt O (2009) Carbon and nitrogen isotope composition of particulate organic matter in relation to mucilage formation in the northern Adriatic Sea. Mar Chem 114:102-109

Fajon C, Cauwet G, Lebaron P, Terzić S and others (1999) The accumulation and release of polysaccharides by planktonic cells and the subsequent bacterial response during a controlled experiment. FEMS Microbiol Ecol 29:351-363

Flander-Putrle V, Malej A (2008) The evolution and phytoplankton composition of mucilaginous aggregates in the northern Adriatic Sea. Harmful Algae 7:752-761

Fonda-Umani S, Ghirardelli E, Specchi M (1989) Gli episodi di 'mare sporco' nell'Adriatico dal 1729 ai nostri giorni. Regione autonoma Friuli - Venezia Giulia, Direzione regionale dell'ambiente, Trieste
Fonda Umani S, Del Negro P, Larato C, De Vittor C and others (2007) Major inter-annual variations in microbial dynamics in the Gulf of Trieste (northern Adriatic Sea) and their ecosystem implications. Aquat Microb Ecol 46:163-175

Giani M, Degobbis D, Rinaldi A (2005a) Mucilages in the Adriatic and Tyrrhenian Seas. Sci Total Environ 353:1-2

Giani M, Berto D, Zangrando V, Castelli S, Sist P, Urbani R (2005b) Chemical characterization of different typologies of mucilaginous aggregates in the Northern Adriatic Sea. Sci Total Environ 353:232-246

Gram L, Grossart HP, Schlingloff A, Kiørboe T (2002) Possible quorum sensing in marine snow bacteria: production of acylated homoserine lactones by Roseobacter strains isolated from marine snow. Appl Environ Microbiol 68: 4111-4116

- Granéli E, Carlsson P, Turner JT, Tester PA, Béchemin C, Dawson R, Funari E (1999) Effects of N:P:Si ratios and zooplankton grazing on phytoplankton communities in the northern Adriatic Sea. I. Nutrients, phytoplankton biomass, and polysaccharide production. Aquat Microb Ecol 18: $37-54$

Grossart HP, Ploug H (2001) Microbial degradation of organic carbon and nitrogen on diatom aggregates. Limnol Oceanogr 46:267-277

Guenet JM (1992) Thermoreversible gelation of polymers and biopolymers. Academic Press, London

Guo L, Santschi PH (2007) Ultrafiltration and its applications to sampling and characterisation of aquatic colloids. In: Wilkinson KJ, Lead JR (eds) Environmental colloids and particles. Wiley, Chichester, p 160-221

Hedges JI, Stern JH (1984) Carbon and nitrogen determinations in carbonate-containing solids. Limnol Oceanogr 29: $657-663$

> Heissenberger A, Leppard GC, Herndl GJ (1996) Ultrastructure of marine snow. II. Microbiological considerations. Mar Ecol Prog Ser 135:299-308

Herndl GJ, Arietta JM, Stoderegger K (1999) Interaction between specific hydrological and microbial activity leading to extensive mucilage formation in the northern Adriatic Sea. Ann Ist Super Sanit 35:405-409

> Kaltenböck E, Herndl GJ (1992) Ecology of amorphous aggregations (marine snow) in the Northern Adriatic Sea. IV. Dissolved nutrients and the autotrophic community associated with marine snow. Mar Ecol Prog Ser 87:147-159

> Kovač N, Faganeli J, Sket B, Bajt O (1998) Characterization of macroaggregates and photodegradation of their water soluble fraction. Org Geochem 29:1623-1634

Kovač N, Bajt O, Faganeli J, Sket B, Orel B (2002) Study of macroaggregate composition using FTIR and ${ }^{1} \mathrm{H}$ NMR spectroscopy. Mar Chem 78:205-215

> Kovač N, Faganeli J, Bajt O, Sket B, Orel B, Penna N (2004) Chemical composition of macroaggregates in the northern Adriatic. Org Geochem 35:1095-1104

> Kovač N, Mozetič P, Trichet J, Défarge C (2005) Phytoplankton composition and organic matter organization of mucous aggregates by means of light and cryo-scanning electron microscopy. Mar Biol 147:261-271

Kovač N, Faganeli J, Bajt O (2008) Mucous macroaggregates in the Northern Adriatic. In: Stefansson O (ed) Geochemistry Research Advances. Nova, New York, NY, p 119-141

$>$ La Ferla R, Leonardi M (2005) Ecological implications of biomass and morphotype variations of bacterioplankton: an example in the coastal zone of the northern Adriatic Sea (Mediterranean). PSZN I: Mar Ecol 26:82-88

Legras JI, Chuzel G, Arnaud A, Galzy P (1990) Natural nitriles and their metabolism. World J Microbiol Biotechnol 6: 83-108 
Leppard GG, Heissenberger A, Herndl GJ (1996) Ultrastructure of marine snow. I. Transmission electron microscopy methodology. Mar Ecol Prog Ser 135:289-298

Løvdal T, Skjoldal EF, Heldal M, Norland S, Thingstad TF (2008) Changes in morphology and elemental composition of Vibrio splendidus along a gradient from carbon-limited to phosphate-limited growth. Microb Ecol 55:152-161

Macko SA, Estep MLF, Engel MH, Hare PE (1986) Kinetic fractionation of stable nitrogen isotopes during amino acid transamination. Geochim Cosmochim Acta 50:2143-2146

Malej A, Harris RP (1993) Inhibition of copepod grazing by diatom exudates: a factor in the development of mucus aggregates? Mar Ecol Prog Ser 96:33-42

Malej A, Petelin B, Cermelj B (2001) Quantification of mucilage-associated suspended matter in the Gulf of Trieste (Adriatic Sea). Ann Ser Hist Nat 11:43-52

Malej A, Mozetič P, Turk V, Terzić S, Ahel M, Cauwet G (2003) Changes in particulate and dissolved organic matter in nutrient-enriched enclosures from an area influenced by mucilage: the northern Adriatic Sea. J Plankton Res 25:949-966

Malfatti F, Azam F (2009) Atomic force microscopy reveals microscale networks and possible symbioses among pelagic marine bacteria. Aquat Microb Ecol 58:1-14

> Manganelli M, Funari E (2003) Le mucillagini nel Mar Adriatico: ruolo dei possibili agenti causali e dei fattori ambientali. Ann Ist Super Sanit 39:77-95

Mingazzini M, Take B (1995) Summary and conclusions of the workshop on marine mucilages in the Adriatic Sea and elsewhere. Sci Total Environ 165:9-14

Moran MA, Belas R, Schell MA, González JM and others (2007) Ecological genomics of marine roseobacters. Appl Environ Microbiol 73:4559-4569

Müller-Niklas S, Schuster S, Kaltenböck E, Herndl GJ (1994) Organic content and bacterial metabolism in amorphous aggregations of the Northern Adriatic Sea. Limnol Oceanogr 39:58-68

Myklestad SM (1999) Phytoplankton extracellular production and leakage with considerations on the polysaccharide accumulation. Ann Ist Super Sanit 35:401-404

Nagata T (2000) Production mechanisms of dissolved organic matter. In: Kirchman DL (ed) Microbial ecology of the oceans. Wiley-Liss, New York, NY, p 121-152

> Nagata T, Meon B, Kirchman DL (2003) Microbial degradation of peptidoglycan in seawater. Limnol Oceanogr 48:745-754

- Najdek M, Degobbis D, Mioković D, Ivančić I (2002) Fatty acid and phytoplankton compositions of different types of mucilaginous aggregates in the northern Adriatic. J Plankton Res 24:429-441

Nishikida K, Hannah RW (1996) Selected applications of modern FT-IR techniques. CRC Press, Boca Raton, FL

> Obernosterer I, Herndl GJ (1995) Phytoplankton extracellular release and bacterial growth: dependence on the inorganic N:P ratio. Mar Ecol Prog Ser 116:247-257

Ogawa H, Amagai Y, Koike I, Kaiser K, Benner R (2001) Production of refractory dissolved organic matter by bacteria. Science 292:917-920

O'Toole G, Kaplan HB, Kolter R (2000) Biofilm formation as microbial development. Annu Rev Microbiol 54:49-79

Pajdak-Stós A, Fialkowska E, Fyda J (2001) Phormidium autumnale (Cyanobacteria) defense against three ciliate grazer species. Aquat Microb Ecol 23:237-244

> Peduzzi P, Weinbauer MG (1993) Effects of concentrating the virus-rich $2-200 \mu \mathrm{m}$ size fraction of seawater on the formation of algal flocs (marine snow). Limnol Oceanogr 38:1562-1565
Penna N, Kovač N, Ricci F, Penna A, Capellacci S, Faganeli J (2009) The role of dissolved carbohydrates in the northern Adriatic macroaggregate formation. Acta Chim Slov 56:305-314

- Ploug H, Grossart HP, Azam F, Jørgensen BB (1999) Photosynthesis, respiration, and carbon turnover in sinking marine snow from surface waters of Southern California Bight: implications for the carbon cycle in the ocean. Mar Ecol Prog Ser 179:1-11

Porter KG, Feig YS (1980) The use of DAPI for identifying and counting aquatic microflora. Limnol Oceanogr 25:943-948

> Posedel N, Faganeli J (1991) Nature and sedimentation of suspended particulate matter during density stratification in shallow coastal waters (Gulf of Trieste, northern Adriatic). Mar Ecol Prog Ser 77:135-145

Raghavan SR, Cipriano BH (2005) Gel formation: phase diagrams using tabletop rheology and calorimetry. In: Weiss RG, Terech P (eds) Molecular gels: materials with self-assembled fibrillar networks. Springer, Amsterdam, p 233-244

- Rath J, Wu KY, Herndl GJ, DeLong EF (1998) High phylogenetic diversity in a marine-snow-associated bacterial assemblage. Aquat Microb Ecol 14:261-269

Sachs JP, Repeta DJ, Goercke R (1999) Nitrogen and carbon isotopic ratios of chlorophyll from marine phytoplankton. Geochim Cosmochim Acta 63:1431-1441

Sauer K, Camper AK, Ehrlich GD, Costerton JW, Davies DG (2002) Pseudomonas aeroginosa displays multiple phenotypes during development as a biofilm. J Bacteriol 184: 1140-1154

Schaudinn C, Stoodley P, Kainović A, O'Keeffe T and others (2007) Bacterial biofilms, other structures seen as mainstream concepts. Microbe 2:231-237

Schiaparelli S, Castellano M, Povero P, Sartoni G, CattaneoVietti R (2007) A benthic mucilage event in North-Western Mediterranean Sea and its possible relationships with the summer 2003 European heatwave: short-term effects on littoral rocky assemblages. PSZN I: Mar Ecol 28:341-353

Simon M, Azam F (1989) Protein content and protein synthesis rates of planktonic marine bacteria. Mar Ecol Prog Ser 51:201-213

Simon M, Grossart HP, Schweitzer B, Ploug H (2002) Microbial ecology of organic aggregates in aquatic ecosystems. Aquat Microb Ecol 28:175-211

Smucker RA, Dawson R (1986) Products and photosynthesis by marine phytoplankton: chitin in TCA 'protein' precipitates. J Exp Mar Biol Ecol 104:143-152

Stachowitsch M, Fanuko N, Richter M (1990) Mucus aggregates in the Adriatic Sea: an overview of stages and occurrences. PSZN I: Mar Ecol 11:327-350

Stoderegger KE, Herndl GJ (1999) Production of exopolymer particles by marine bacterioplankton under contrasting turbulence conditions. Mar Ecol Prog Ser 189:9-16

Studer D, Humbel BM, Chiquet M (2008) Electron microscopy of high pressure frozen samples: bridging the gap between cellular ultrastructure and atomic resolution. Histochem Cell Biol 130:877-889

Supić N, Orlić M (1999) Seasonal and interannual variability of the northern Adriatic surface fluxes. J Mar Syst 20: 205-229

Svetličić V, Žutić V, Hozić Zimmermann A (2005) Biophysical scenario of giant gel formation in the Northern Adriatic Sea. Ann NY Acad Sci 1048:524-527

- Thingstad TF, Hagström Å, Rassoulzadegan F (1997) Accumulation of degradable DOC in surface waters: Is it caused by a malfunctioning microbial loop? Limnol Oceanogr 42:398-404 
Thingstad TF, Øvreås L, Egge JK, Løvdal T, Heldal M (2005) Use of non-limiting substrates to increase size: a generic strategy to simultaneously optimize uptake and minimize predation in pelagic osmotrophs? Ecol Lett 8:675-682

> Trichet J, Défarge C, Tribble J, Tribble G, Sansone F (2001) Christmas Island lagoonal lakes, models for the deposition of carbonate-evaporite-organic laminated sediments. Sediment Geol 140:177-189

$>$ Verdugo P, Alldredge AL, Azam F, Kirchman DL, Passow U, Santschi PH (2004) The oceanic gel phase: a bridge in the DOM-POM continuum. Mar Chem 92:67-85

Submitted: April 12, 2010; Accepted: August 12, 2010
Whiteley M, Bangera MG, Bumgarner RE, Parsek MR, Teitzel GM, Lory S, Greenberg EP (2001) Gene expression in Pseudomonas aeroginosa biofilms. Nature 413: 860-864

Zaccone R, Caruso G, Cal C (2002) Heterotrophic bacteria in the northern Adriatic Sea: seasonal changes and ectoenzyme profile. Mar Environ Res 54:1-19

Zoppini A, Puddu A, Fazi S, Rosati M, Sist P (2005) Extracellular enzyme activity and dynamics of bacterial community in mucilaginous aggregates of the northern Adriatic Sea. Sci Total Environ 353:270-286

Proofs received from author(s): October 20, 2010 